\title{
Municipal Service Delivery: The Role of Transaction Costs in the Choice between Alternative Governance Mechanisms
}

\author{
MIGUEL RODRIGUES*, ANTONIO F. TAVARES** \& \\ J. FILIPE ARAÚJO** \\ *School of Communication, Administration and Tourism, Bragança Polytechnic Institute; and \\ School of Economics and Management, University of Minho, Portugal, **School of Economics \\ and Management, University of Minho, Portugal
}

\begin{abstract}
Service provision by local governments can be delivered using in-house bureaucracies, private firms, and partnerships with other governments or the not-forprofit sector. This production decision has been a major focus of discussion among scholars, practitioners and political agents for the last quarter of a century. The transaction costs framework is an important tool to analyse decisions regarding the production of local services. In this paper, the authors employ this framework to analyse service delivery in Portugal and find that service characteristics and the local political environment play a key role in local officials' choice among the three governance mechanisms to deliver public services.
\end{abstract}

KEY WORDS: Service delivery, transaction costs, governance mechanisms

Due to their level of proximity and periodic transfers of competences from the national government, local governments in Portugal gained importance over the past two decades as service providers. Their functional responsibilities have been extended significantly over several areas including water supply, promotion of regional development, solid waste collection, emergency management, health care, education, and land use management, among many others. To cope with all these challenges, local governments changed from a general, multi-purpose organisation to a complex network of relationships with other public bodies, private agents, and not-for-profit organisations.

Correspondence Address: Professor Antonio F. Tavares, Centre for Research on Public Administration and Policy, Department of International Relations and Public Administration, School of Economics and Management, University of Minho (Campus de Gualtar), 4710-057 Braga, Portugal. E-mail: atavares@eeg.uminho.pt 
The choice of local officials regarding service delivery options has been an issue of debate over the past quarter century both in the academic and practitioner literatures. Prior research highlights the role of service type, the level of political and administrative turnover, and the socioeconomic and demographic status of the jurisdiction as relevant factors influencing the decision (Stein 1993; Clingermayer, Feiock \& Stream 2003; Feiock, Clingermayer, \& Dasse 2003; Joassart-Marcelli \& Musso 2005; Brown, Potoski, \& Van Slyke 2006; Carr, LeRoux \& Shrestha 2009; Feiock and Jang 2009; Shrestha \& Feiock 2010). The significant amount of research in the US context contrasts sharply with the limited scope of analysis in Europe, where most research focuses in dyadic choices - e.g. public versus private or public versus not-for-profit options - rather than analysing the three sectors simultaneously. One notable exception to this rule examines the use of mixed public-private firms as a partial privatisation strategy for water distribution and solid waste collection services (Bel \& Fageda 2010).

This work begins to fill this important lacuna by testing a transaction costs model of service delivery with data from municipal governments in a European setting. Specifically, we collected data on service provision and production choices in Portugal and employ these data to test a transaction costs model of service delivery options by a sample of Portuguese local governments. The transaction costs framework suggests that there are costs in adopting external solutions resulting from bounded rationality and opportunistic behaviour by the agents. As transaction costs increase, the production cost efficiency gains from externalisation become less decisive. Service complexity, asset specificity, and the local political environment influence the level of transaction costs and hence the decision to externalise the service.

The transaction costs hypotheses are tested using a multinomial logit regression model. This test is an extension of other efforts reported in the literature and the goal is to cast contracting choices as delegation decisions involving economic and political transaction costs. The survey of Portuguese local governments allowed us to identify a total of twelve government arrangement alternatives to deliver public services. These twelve alternatives are organised in three 'classic' governance mechanisms hierarchy, market, and partnerships/networks - according to a set of predefined criteria. We measure the economic and political transaction costs involved in service delivery while controlling for other contextual factors affecting the decision choice.

The first section summarises the literature of the application of the transaction costs framework to the choice of service delivery mechanisms. Next, we develop the theory and present a series of hypotheses linking transaction costs with service production choices. The third section describes the context of our study highlighting both the historical constraints associated with production choices in Portugal and the relevance of this study for gaining additional understanding of local governments in 
Southern European countries. Data and methods are presented in section four and the findings reported in section five. The piece closes with a brief set of conclusions and implications for future research.

\section{Literature background}

The transaction costs framework (TCF) is frequently used by scholars as an important tool to explain the choice between different alternatives to deliver public services (Brown \& Potoski 2003; Lamothe, Lamothe, \& Feiock 2008; Tavares \& Camões 2007, 2010). Robert Stein (1993) employs service typologies developed by Ostrom and Ostrom (1977) and Peterson (1981) to support the argument that government service delivery arrangements are a function of the nature and scope of the service to be provided. Ferris and Graddy $(1986 ; 1991)$ point out the nature of the service as the main factor in decision making and highlight the challenges that local governments face when contracting out with private vendors. Building on the work of Ronald Coase (1937) and Oliver Williamson (1981; 1985; 1996) on transactions costs, Brown and Potoski $(2003 ; 2005)$ argue that local government choices are driven by the degree of asset specificity and service measurability involved in the decision to provide local services.

The key argument of the TCF states that the comparative analysis of financial costs of the capital invested, personnel, and property costs (production costs) is insufficient to justify the choice of one of the alternative mechanisms to deliver public services. The costs associated with negotiating, monitoring, and enforcing contracts with external vendors must also be considered, as transaction costs, in the analysis of alternative forms of production (Brown \& Potoski 2003). The decision to produce a service through an in-house bureaucracy, externalise it to a private vendor or resort to other government or not-for-profit organisation is influenced by the transaction costs of service delivery associated with service characteristics and political context. Thus, the most appropriate governance mechanism is the one that minimises the transaction costs of service delivery (Brown \& Potoski 2003, Nelson 1997; Ferris \& Graddy 1997; Feiock, Clingermayer, Shrestha, \& Dasse 2007).

Transaction costs result from bounded rationality and agent opportunism involved in contractual agreements and vary according to service characteristics, including the specificity of assets, service measurability, and the frequency of transactions (Coase 1937; Williamson 1985). Better productive efficiency can be achieved through private production because production costs tend to be lower in the private sector. However, external delivery choices involve transaction costs stemming from the need to mitigate agent opportunism in contractual agreements. When total costs are considered, in-house options may actually become more efficient alternatives (Nelson 1997). Empirical work by Bel and Fageda (2010) compares the use of mixed firms with pure public and pure private production options 
and finds that private production is less likely for services displaying high transaction costs.

The consideration of total costs involves not only the economic transaction costs related with service characteristics but also the 'political' transaction costs linked with the political environment of service delivery. While economic transaction costs are directly related to the characteristics of the goods or services being contracted, political transaction costs are external to the transaction but may constrain the choice of the production mechanism to be employed. The model presented here accounts for both types of transaction costs associated with service delivery choices.

\section{Service characteristics, political environment and production choices}

When deciding to provide specific services, local government officials are faced with alternative mechanisms to produce these services. The choice involves three major components: the characteristics of the service, a set of external constraints, and the production alternatives available. This section is concerned with the first two aspects of the production decision. The next section tackles the last.

\subsection{Economic transaction costs}

Economic transaction costs are associated with the uncertainty involved in contracting with external agents (other governments, nonprofit organisations or private firms) for service production. Contractual agreements entail both ex-ante and ex-post problems derived from bounded rationality and opportunism. Adverse selection is associated with hiring an agent that will not fulfill the contractual terms, something that the hiring government cannot perfectly detect in advance due to bounded rationality. In order to overcome adverse selection, local officials face costs involved in the process of searching, selecting and hiring the agent in a context of imperfect information.

Moral hazard occurs ex-post and can be regarded as the cost of monitoring the agent's effort and/or performance. In the absence of perfect information, the agent can behave opportunistically by failing to uphold the terms of the contract. Monitoring activities entail costs that increase with service complexity, e.g., opportunistic behavior is easier to monitor in the case of a solid waste collection company than in mental health care services.

Adverse selection and moral hazard are closely associated with two service characteristics: asset specificity and service complexity. In general, it can be argued that economic transaction costs increase either when contracting for highly specific assets or when monitoring highly complex services.

Asset specificity increases transaction costs because specific and specialised investments and skills are difficult to redeploy in alternative uses in 
public service production. After the first round of procurement, contract agreements for asset specific goods and services lock buyer and seller in a bilateral monopoly. The contracting government is a single service purchaser who attributes the first contract to the best bidder who in turn becomes vulnerable to the monopsony. Since the investments are highly specific the winner develops a competitive advantage over other vendors in future contracts. As competition for future procurement decisions is reduced, the local government becomes exposed to opportunism on the part of the initial winner (Williamson 1985; Brown, Potoski, \& Van Slyke 2006).

The externalisation of asset specific goods and services can result in a fundamental transformation, whereby the initial large numbers bidding is converted into an ex-post bilateral supply (Williamson 1985: 61). As a result, services involving highly specific assets tend to be provided by hierarchical mechanisms, while services with low asset specificity are provided using market solutions (Coase 1937; Williamson 1981, 1985; Ferris \& Graddy 1997; Nelson 1997).

Recent empirical findings point to a more complex relationship between asset specificity and externalisation. Brown and Potoski (2003) suggest and find support for the idea that local governments turn to external service providers because highly specific assets have also capital-intensive cost structures. Shrestha and Feiock (2010) argue that the relationship between asset specificity and externalisation follows an inverted U-shape. Intergovernmental contracting is more likely at mid-range levels of asset specificity, while in-house production predominates at very high levels and private contracting is more frequent at lower levels. Carr, LeRoux, and Shrestha (2009) find support for this nonlinear relationship, particularly that at very high levels of asset specificity local governments avoid nongovernmental producers. Based on the theoretical arguments by Williamson (1985) and the findings by Carr, LeRoux, and Shrestha (2009), we hypothesise that:

Hypothesis 1: Services involving highly specific assets are less likely to be provided by market mechanisms.

Hypothesis 2: When externalisation is an alternative to hierarchic mechanisms, local officials are more likely to partner with other governments or nonprofit organisations to produce highly specific assets.

Service measurability refers to the degree of difficulty to evaluate service outcomes and monitor the performance of the agent. According to the assumptions of transaction costs theory, service measurability is a problem due to information asymmetry because the presence of both bounded rationality and opportunism leads to moral hazard contractual problems (Williamson 1985). Service activities that are easy to measure are more 
suitable to be described in a formal contract and therefore more amenable to external production. In contrast, complex and/or intangible activities are less amenable to monitoring by the contractor, so transaction costs increase significantly for contracting out these activities.

Past findings in the empirical literature indicate a significant degree of support for this service complexity hypothesis (Brown \& Potoski 2003; Levin \& Tadelis 2007). However, recent empirical work points out that there are situations of externalisation to nonprofit organisations, even in the case of complex services (Lamothe, Lamothe, \& Feiock 2008; Feiock and Jang 2009). Presumably this occurs due to the fundamental differences in terms of values and goal congruence between the private and the public and not-forprofit sectors. Profit maximisation constitutes a high-powered incentive for private firms that can lead to a decline in service quality to reduce costs (Frant 1996). The efficiency gains associated with contracting out with private firms, particularly in the case of labour intensive services, are counterweighted by potential opportunistic behavior on the part of profitseeking firms (Ferris \& Graddy 1986; Lamothe, Lamothe, \& Feiock 2008; Feiock and Jang 2009). The incentives to opportunism are less prevalent in the public and not-for-profit sectors, where slack resources are reinvested in organisational activities or reverted back to organisational budgets. Hence, when externalisation is considered for efficiency reasons, the use of network mechanisms is more likely, namely the establishment of partnerships with other public agencies or third sector actors.

Hypothesis 3: Services that are complex and/or difficult to measure are less likely to be provided through market mechanisms.

Hypothesis 4: When externalisation is an option, local officials prefer partnerships with other governments or nonprofit organisations to produce complex and/or intangible services.

\subsection{Political transaction costs}

Political transaction costs result from the context where the service is provided and lead to limitations of sector choice by local officials. In other words, in the presence of political transaction costs local officials see the number of service production alternatives reduced due to factors which are not directly related with the contractual decision, but stem from the context where this decision takes place. Political transaction costs are not 'political' in the partisanship sense, but linked with the credibility of the local government in a contractual exchange (North 1990; Dixit 1996).

An adverse political environment reduces the attractiveness of service contracts because it creates uncertainty for potential private and not-forprofit organisations due to the possibility of government reneging on contractual agreements. Political and/or administrative instability in the 
local executive can adversely impact the level of transaction costs and reduce the alternatives regarding service delivery. Recent work by Feiock and Jang (2009) confirms this argument by finding a negative relationship between mayoral turnover and nonprofit contracting for services for the elderly.

Having the same executive for several consecutive terms may be translated into greater confidence and expectation of credible commitment to establish contracts. According to Feiock, Clingermayer, and Dasse (2003), this stability facilitates the use of external agents in the provision of public services. However, the same authors alert us to a possible exception to this effect. A higher level of political instability may also be an incentive to the externalisation of public services in order to shift blame to the providers (Frant 1996; Clingermayer \& Feiock 1997; Hood 1998). In this case, the use of nonprofit organisations or partnerships with other governments may be a more viable alternative than private firms. Local officials are able to duck blame while at the same time overcoming the absence of private vendors willing to enter contractual agreements due to political and/or administrative instability. In light of these findings, we posit that:

Hypothesis 5: Political instability decreases the probability of adoption of market alternatives and increases the likelihood of using partnerships rather than hierarchical solutions.

Hypothesis 6: Administrative instability decreases the probability of adoption of market alternatives and increases the likelihood of using partnerships rather than hierarchical solutions.

The relationship between financial status and the decision to outsource the provision of public services has been a matter of strong contention in the empirical literature. The dominant view in the public administration literature is that adverse financial situations lead to the adoption of external arrangements rather than in-house hierarchical solutions. With reduced financial capacity the need to provide public services at reduced costs leads local governments to use markets and/or partnerships, as external procurement is expected to be more innovative and cost effective (Ferris 1986; Brown, Potoski, \& Slyke 2006).

However, empirical findings in the field of economics suggest that contracting out at the local level may actually be more prevalent during economic upturns (Borcherding 1988; Wittman 1989; see also Pallesen 2004). This argument underlines that the externalisation of services to achieve technical efficiency and cost savings during economic austerity ignores the transaction costs associated with externalisation decisions. When transaction costs are accounted for "it may very well make it rational for the city to produce the service in-house" (Nelson 1997, p. 84).

This argument is also in line with the idea that financial crises reduce the leverage of local governments over their options. Externalisation involves 
unacceptable political and electoral risks due to the loss of political control in fundamental service delivery areas. Consistently, it can be argued that contracting out is primarily a political decision and, as a result, it can only be undertaken when public revenues and expenditures are easier to increase in order to reduce public employee resistance. Where local public sector unions are stronger, such as in highly decentralised countries, opposition to contracting out may be especially vigorous during economic decline (Pallesen 2004).

Hypothesis 7: Jurisdictions facing fiscal stress are less likely to externalise their services.

\subsection{Control variables}

Community characteristics can also affect the decision of the production alternative to be employed. Communities facing significant economic and demographic changes are more likely to resort to externalisation, either through contracting out with private vendors or by establishing partnerships with the not-for-profit sector. Heterogeneous communities display increased preference diversity and citizen demands over local government service provision (Clingermayer, Feiock, \& Stream 2003; Feiock and Jang 2009). Preference diversity in a local jurisdiction varies positively with the increase in personal income per capita, population growth, density, and urbanisation. Organisation theory suggests that jurisdictions facing such pressures are more likely to diversify their service delivery options, since hierarchical mechanisms seem more appropriate for stable environments (Weber 1947; Alexander 1995; Beetham 1991; Blau \& Meyer 1971). In dynamic environments, with greater levels of functional complexity, more flexible solutions are expected (Burns and Stalker 1961).

\section{Local service delivery in the Portuguese context}

The decision to provide specific services involves the consideration of all possible alternatives to produce each service provided by local governments. The last section employed a transaction costs framework to address two important features of this choice: the characteristics of the service to be produced and the external constraints that can influence the outsourcing decision. This section is concerned with the production alternatives available to local government officials. The discussion is framed by the history and the evolution of functional responsibilities of local governments in Portugal.

Local governments deliver public services using a complex set of organisational choices. Hierarchy is the coordination mechanism most commonly used by Portuguese local governments (Rodrigues 2009) and it is considered the most natural and efficient way to manage bureaucratic 
organisations in a stable environment (Weber 1947; Alexander 1995; Beetham 1991; Verhoest, Peters, Beuselinck, Meyers, \& Bouckaert 2004).

Local governments in Portugal have a longstanding tradition and most municipalities (concelhos) have existed with significant autonomy since the Middle Ages. They had autonomy to manage the municipality in what concerns their land, commerce transportation regulations and markets, road construction and maintenance, local income and price taxes, and police power, among others (Manique 1989). In the nineteenth century, municipal autonomy was suspended. The liberal regime attempted to rationalise the administrative system and to control municipalities by embracing the French Napoleonic structure of administration. The debate about the territorial division and organisation was inspired by the French administration. Over time, centralisation and state power turned the country into a highly centralised administrative state (Livermore 1976).

The advent of the republican regime in the early years of the twentieth century and particularly the authoritarian administration of the Estado Novo (1926-1974) reinforced the centralised pattern of Portuguese institutions. The regime developed a corporative and autocratic emphasis, strengthened the importance of the administrative bureaucracy, and introduced institutional uniformity. During the dictatorship period, municipalities had limited competencies and operated as an extension of the national government. For a period of almost 50 years, municipalities essentially played a role as administrative units of the state (Opello 1983), acting as administrative agencies organising activities in-house according to a single structure model of local service delivery.

Services responsible for the preparation and implementation of administrative decisions were organised as hierarchical structures, the Municipal Services (Serviços Municipais) (Oliveira 1996). For services of an economic and industrial nature, such as water distribution, electricity, sewage, garbage collection, and public transportation, local governments were allowed to create Municipalised Services (Serviços Municipalizados), under certain conditions established by law (Pereira \& Almeida 1985, p. 214). Approved by the Municipal Assembly (deliberative body), these services had some financial autonomy and an Executive Board, but stopped short of having corporate-like status, since the municipality was the sole owner and they remained hierarchically integrated in the municipality (Caetano 1982).

The democratic regime introduced in 1974 and the Portuguese Constitution of 1976 re-established democratic local power, new service delivery roles, and financial and administrative autonomy. As new competences were ascribed to local governments, citizens became more aware of their role and the central government started a new era of intergovernmental relations based on three basic principles: local autonomy, decentralisation, and subsidiarity.

The new functional competencies and the political, social, and economic development pressured the emergence of new forms of local service delivery. However, New Public Management ideas and organisational forms are 
latecomers in the Portuguese local government scene. The continental Europe juridical tradition of administrative reform emphasised changes in legislation, not managerial changes (Rodrigues and Araújo 2006). The country's history and political culture also contribute to explain this resistance to market alternatives and the predominance of state-oriented production choices (Tavares \& Camões 2007, p. 537).

Nevertheless, it is possible to identify some changes in public service delivery based on market type mechanisms and the use of private management tools. By the mid 1980s, local governments began using contracting-out or franchising as alternatives to in-house solutions. The relationship between local governments and private agents was based on contractual agreements between the parties in a competitive environment.

Since the late 1990s, local governments were authorised to create Municipal and Inter-municipal Corporations. These have corporate-like status and administrative, financial and patrimonial autonomy, and are regulated by the law of public corporations and by the commercial society's code. In theory, this solution resembles the use of externalisation, since it shifts public service production to a different agent than the local government. However, municipal power remains untouched since local governments decide the creation, modification and termination of the corporations and control appointments to their managerial boards. In practice, both financial and personnel management are often integrated as local governments are forced to consolidate accounts and employees can be transferred from the in-house bureaucracy to the corporation payroll and vice-versa.

More recently, local government extended the use of partnership mechanisms to provide services to their citizens. Partnerships with nonprofit organisations and other governments are now regarded as viable options to provide municipal services, particularly in the field of social policy (elderly care services, child care, social housing, and health care). While contracting out requires special care with contractual writing, monitoring and evaluation activities, partnerships with not-for-profit organisations provide some of the market advantages, but are based on reciprocity, shared goals and values, and information facilitation through voluntary participation of all actors (Feiock, Clingermayer, Shrestha, \& Dasse 2007).

Local governments have also created commercial companies. In some cases, these new entities were created with other municipalities (Municipal Commercial Societies), with the central government (Public Commercial Societies), and with private agents (Mixed Commercial Societies). In the first two types, the split of decision powers indicates these classify as partnerships, while in the last case the municipality is a minority shareholder in a private firm.

In sum, local government officials are able to choose from a total of twelve alternatives available to produce services. Not all twelve alternatives are actually available to all services provided by local governments in Portugal, as many do not have the market opportunities or potential 
nonprofit partners to contract with (Rodrigues 2009). The complete list is depicted in table 1.

These organisations of service delivery can be classified according to broad governance arrangements (hierarchy/market/network). Table 1 uses a set of organisational features to classify each service delivery arrangement within a governance mechanism. We use the direct control criteria for hierarchic type mechanisms (HTM), competition criteria for market type mechanisms (MTM), and inter-organisational cooperation criteria for network type mechanisms (NTM).

\section{Data and methods}

In presenting our hypotheses, we discussed several determinants of the choice between alternative governance mechanisms. The variables included in the analysis concern service features, political environment, and community characteristics measured by the indicators described in Table 2 .

During the year 2008, we conducted an electronic survey of local government officials in 278 municipalities in Continental Portugal. We received 101 valid responses, corresponding to a $36.3 \%$ response rate. Our dependent variable is the governance mechanism chosen by the 101 municipalities to provide 42 different services. The total number of observations included in the analysis is significantly reduced because not all services are provided by the respondents.

Following procedures by Brown and Potoski (2003; 2004, 2005), Levin and Tadelis (2007), Feiock, Clingermayer, Shrestha, and Dasse (2007), and LeRoux (2007), we assess the level of asset specificity and service measurability by asking officials to rate each municipal service on two scales from 1 (low) to 5 (high) asset specificity and from 1 (low) to 5 (high) service complexity. Since both service characteristics are related to the provisions defined in the contractual agreement, the perception of local officials is most likely the best approximation to measuring these features. The survey provided assistance to the respondents by clarifying the concepts of asset specificity and service complexity. Asset specificity was defined as (Brown \& Potoski 2005, p, 329):

"the use of a specific location that is only movable at a great cost; the use of highly specialised human skills that cannot be put to work for other purposes; the use of specialised tools or a complex system designed for a single purpose; the requirement that the service reach the user within a relatively limited period of time or the quality of the service greatly diminishes."

When dealing with service complexity, again we clarify the concept (Brown \& Potoski 2005, p. 335): "government officials can easily write a contract and clearly specify the activities and outcomes for the vendor to perform 
M. Rodrigues et al.

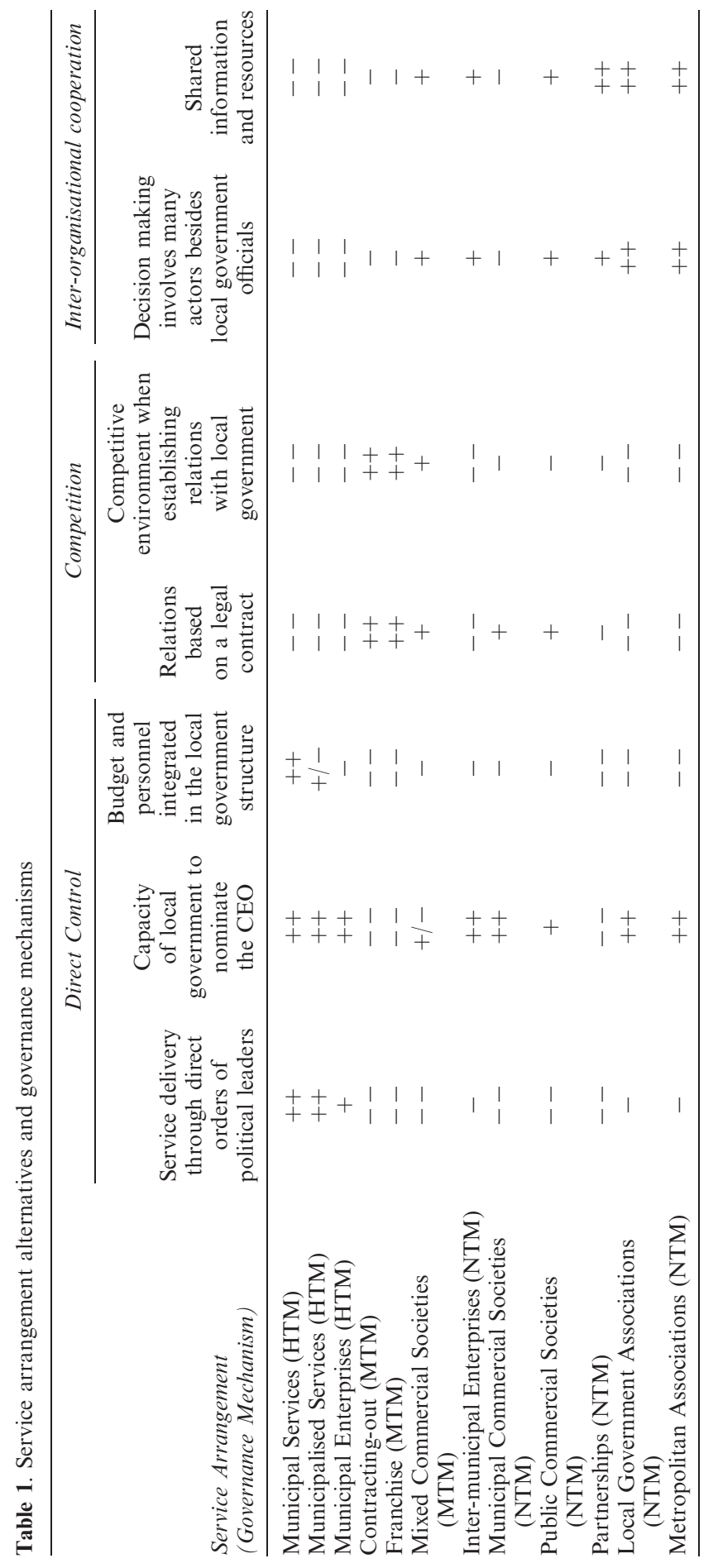


Table 2. Variable description and sources

\begin{tabular}{|c|c|c|}
\hline Variable & Description & Source \\
\hline Governance mechanism & $\begin{array}{l}\text { Dependent Variable; Measures the choice } \\
\text { between alternatives. Takes the values } \\
\text { of } 1=\text { Hierarchy; } 2=\text { Market; } \\
3=\text { Network. }\end{array}$ & $\begin{array}{l}\text { Direct Survey to } \\
\text { Municipalities } \\
\text { (2008) }\end{array}$ \\
\hline Asset specificity & $\begin{array}{l}\text { Likert scale ranging from } 1 \text { (low) to } 5 \\
\text { (high) }\end{array}$ & Survey (2008) \\
\hline Service complexity & $\begin{array}{l}\text { Likert scale ranging from } 1 \text { (low) to } 5 \\
\text { (high) }\end{array}$ & Survey (2008) \\
\hline Politicals & $\begin{array}{l}\text { Likert scale ranging from } 1 \text { (low) to } 5 \\
\text { (high) }\end{array}$ & Survey (2008) \\
\hline Administrative stability & $\begin{array}{l}\text { Likert scale ranging from } 1 \text { (low) to } 5 \\
\text { (high) }\end{array}$ & Survey (2008) \\
\hline Financial dependency & $\begin{array}{l}\text { Financial dependency is the proportion of } \\
\text { central government grants in total local } \\
\text { revenues }\end{array}$ & $\begin{array}{l}\text { Financial Yearbook } \\
\quad(2006)\end{array}$ \\
\hline Net debt & $\begin{array}{l}\text { Total local budgetary balance (a negative } \\
\text { number is a deficit) }\end{array}$ & $\begin{array}{l}\text { Financial Yearbook } \\
\text { (2006) }\end{array}$ \\
\hline ISD & $\begin{array}{l}\text { Index of social development as measured } \\
\text { by Portuguese government }\end{array}$ & INE (2006) \\
\hline Income & Personal income per capita & INE (2006) \\
\hline Population growth & Rate of population growth (2001-2006) & INE (2006) \\
\hline Area & Area in square kilometers & INE (2006) \\
\hline Population density & Population per square kilometer & INE (2006) \\
\hline Urban Land & Proportion of urban land in total area & INE (2006) \\
\hline
\end{tabular}

and achieve; government officials can monitor the quality and quantity of these activities and their outcomes".

Political and administrative stability are measured following a similar procedure as suggested by Feiock, Clingermayer, and Dasse (2003). For each indicator (administrative and political) we asked the respondents to rate on a scale from 1 (less stability) to 5 (more stability) the classification that best suited their jurisdiction. The indicators to gauge the financial status of the municipality are extracted from the Financial Yearbook of Portuguese Local Governments edited by Carvalho, Fernandes, Jorge, and Camões (2006) and published by the Center for Research in Public Policy and Administration. Financial dependency is the proportion of central government grants in total local revenues. Net debt is calculated as the total local budgetary balance. The first variable gauges the long-term financial status of the local community, whereas the second variable is primarily a short-term measure of budgetary stress.

In order to control for community characteristics, we employ a diverse set of indicators that taps into different aspects of local dynamics. Socioeconomic status is gauged by personal income per capita and by a social development index (SDI) calculated as the average of three indexes: life expectancy, educational level, and basic local infrastructure coverage. The SDI varies from 0 to 1 . Demographic trends are accounted for by the rate of 
population growth, area, and population density. These indicators also control for possible scale economies associated with local service production. We control for the economic profile of the community by including the proportion of urban land use. Data were retrieved from the National Bureau of Statistics (INE 2006). All variables and indicators are summarised in Table 2 and descriptive statistics are included in Table 3.

The dependent variable assumes one of three possible nominal outcomes: hierarchy (coded 1), market (coded 2), and networks/partnerships (coded 3). Table 4 presents a complete description of our dependent variable, including the number of municipal governments providing each of the 42 services in our data set, as well as the production decisions associated with each of the services. Most services are produced through in-house bureaucracies. There are a few exceptions to this rule, namely electrical power, health care services, public transportation, and solid waste treatment. Out of 4,242 possible provision decisions, the 101 local governments included in our sample provide 2,843 services, the vast majority produced by in-house bureaucracies or other hierarchical variations (77.7\%). Markets are used in 319 cases $(11.22 \%)$ and networks/partnerships in $315(11.08 \%)$.

The literature indicates that the multinomial logit model is the most appropriate for estimating unordered, multi-category dependent variables, as this is an extension of the binary logit regression model when the dependent variable is no longer dichotomous but a nominal one (Borooah 2002, Aldrich \& Nelson 1984; Liao 1994). The model assumes a reference category (in our case, hierarchy), and provides the odds, in probabilistic terms, of the other categories (market and networks) (Borooah 2002, Aldrich \& Nelson 1984; Liao 1994). This econometric model uses maximum likelihood for estimating regression coefficients. This method is used in logit models because the errors do not follow a normal distribution and do not have constant variance. Robust standard errors are calculated with the Huber/White/Sandwich (HWS) variance estimator.

Table 3. Independent variables descriptive statistics

\begin{tabular}{lcccc}
\hline & Mean & Standard deviation & Maximum & Minimum \\
\hline Asset specificity & 3.40 & .98 & 5 & 0 \\
Service complexity & 2.65 & 1.12 & 5 & 0 \\
Political stability & 4.54 & .64 & 5 & 3 \\
Administrative stability & 4.48 & .59 & 5 & 3 \\
Financial dependency & .37 & .21 & .87 & .07 \\
Net debt & $2.60 \mathrm{e}+07$ & $7.74 \mathrm{e}+07$ & $7.35 \mathrm{e}+08$ & $-1.43 \mathrm{e}+07$ \\
Social Development Index & .90 & .024 & .94 & .831 \\
Income per capita & 731.57 & 161.4 & 1523.05 & 546.13 \\
Population growth rate & .34 & 6.82 & 24.47 & -10.44 \\
Area & 302.12 & 251.25 & 1232.94 & 7.94 \\
Population density & 377.27 & 853.78 & 6015.50 & 10.49 \\
Proportion of urban land & .12 & .14 & .635 & .004 \\
\hline
\end{tabular}


Table 4. Provision and production choices for 42 services

\begin{tabular}{|c|c|c|c|c|c|c|c|c|}
\hline \multirow{3}{*}{$\frac{\text { Services }}{\text { Airports }}$} & \multirow{2}{*}{\multicolumn{2}{|c|}{$\begin{array}{l}\text { Provision } \\
\text { Service } \\
\text { Provided }\end{array}$}} & \multicolumn{6}{|c|}{ Production Decision } \\
\hline & & & \multicolumn{2}{|c|}{ Hierarchy } & \multicolumn{2}{|r|}{ Market } & \multicolumn{2}{|c|}{ Network } \\
\hline & 12 & $(11.88 \%)$ & 9 & $(75.00 \%)$ & 2 & $(16.67 \%)$ & 1 & $(8.33 \%)$ \\
\hline Ambulance /EMS & 56 & $(55.45 \%)$ & 30 & $(53.57 \%)$ & 1 & $(1.79 \%)$ & 25 & $(44.64 \%)$ \\
\hline Animal control & 59 & $(58.42 \%)$ & 42 & $(71.19 \%)$ & 1 & $(1.69 \%)$ & 16 & $(27.12 \%)$ \\
\hline Beautification & 92 & $(91.09 \%)$ & 78 & $(84.78 \%)$ & 12 & $(13.04 \%)$ & 2 & $(2.17 \%)$ \\
\hline Building maintenance & 71 & $(70.30 \%)$ & 60 & $(84.51 \%)$ & 11 & $(15.49 \%)$ & 0 & $(0.00 \%)$ \\
\hline Building security & 67 & $(66.34 \%)$ & 44 & $(65.67 \%)$ & 23 & $(34.33 \%)$ & 0 & $(0.00 \%)$ \\
\hline $\begin{array}{l}\text { Canteen service } \\
\text { provision }\end{array}$ & 40 & $(39.60 \%)$ & 29 & $(72.50 \%)$ & 8 & $(20.00 \%)$ & 3 & $(7.50 \%)$ \\
\hline Cemetery services & 89 & $(88.2 \%)$ & 87 & $(97.75 \%)$ & 2 & $(2.25 \%)$ & 0 & $(0.00 \%)$ \\
\hline Childcare services & 74 & $(73.27 \%)$ & 69 & $(93.24 \%)$ & 1 & $(1.35 \%)$ & 4 & $(5.41 \%)$ \\
\hline City planning & 98 & $(97.03 \%)$ & 95 & $(96.94 \%)$ & 2 & $(2.04 \%)$ & 1 & $(1.02 \%)$ \\
\hline Code enforcement & 87 & $(86.14 \%)$ & 84 & $(96.55 \%)$ & 2 & $(2.30 \%)$ & 1 & $(1.15 \%)$ \\
\hline $\begin{array}{l}\text { Convention centres } \\
\text { and auditoriums }\end{array}$ & 78 & $(77.23 \%)$ & 72 & $(92.31 \%)$ & 1 & $(1.28 \%)$ & 5 & $(6.41 \%)$ \\
\hline $\begin{array}{l}\text { Economic/industrial } \\
\text { facilities }\end{array}$ & 34 & $(33.66 \%)$ & 28 & $(82.35 \%)$ & 1 & $(2.94 \%)$ & 5 & $(14.71 \%)$ \\
\hline Electricity & 46 & $(45.54 \%)$ & 3 & $(6.52 \%)$ & 32 & $(69.57 \%)$ & 11 & $(23.91 \%)$ \\
\hline Foreign relations & 56 & $(55.45 \%)$ & 52 & $(92.86 \%)$ & 0 & $(0.00 \%)$ & 4 & $(7.14 \%)$ \\
\hline Health care services & 35 & $(34.65 \%)$ & 8 & & 13 & $(37.14 \%)$ & 14 & $(40.00 \%)$ \\
\hline Housing & 69 & $(68.32 \%)$ & 65 & $(94.20 \%)$ & 0 & $(0.00 \%)$ & 4 & $(5.80 \%)$ \\
\hline Industrial facilities & 44 & $(43.56 \%)$ & 39 & $(88.64 \%)$ & 4 & $(9.09 \%)$ & 1 & $(2.27 \%)$ \\
\hline Library & 87 & $(86.14 \%)$ & 87 & $(100.00 \%)$ & 0 & $(0.00 \%)$ & 0 & $(0.00 \%)$ \\
\hline Museums & 57 & $(56.44 \%)$ & 56 & $(98.25 \%)$ & 0 & $(0.00 \%)$ & 1 & $(1.75 \%)$ \\
\hline Parking services & 42 & $(41.58 \%)$ & 30 & $(71.43 \%)$ & 12 & $(28.57 \%)$ & 0 & $(0.00 \%)$ \\
\hline $\begin{array}{l}\text { Parking structures } \\
\text { and facilities }\end{array}$ & 57 & $(56.44 \%)$ & 47 & $(82.46 \%)$ & 10 & $(17.54 \%)$ & 0 & $(0.00 \%)$ \\
\hline Police & 17 & $(16.83 \%)$ & 16 & $(94.12 \%)$ & 0 & $(0.00 \%)$ & 1 & $(5.88 \%)$ \\
\hline $\begin{array}{l}\text { Poverty prevention } \\
\text { programs }\end{array}$ & 79 & $(78.22 \%)$ & 57 & $(72.15 \%)$ & 0 & $(0.00 \%)$ & 22 & $(27.85 \%)$ \\
\hline Public bus system & 47 & $(46.53 \%)$ & 19 & $(40.43 \%)$ & 27 & $(57.45 \%)$ & 1 & $(2.13 \%)$ \\
\hline Recreation facilities & 89 & $(88.12 \%)$ & 83 & $(93.26 \%)$ & 2 & $(2.25 \%)$ & 4 & $(4.49 \%)$ \\
\hline Road maintenance & 85 & $(84.16 \%)$ & 56 & $(65.88 \%)$ & 29 & $(34.12 \%)$ & 0 & $(0.00 \%)$ \\
\hline School bus & 89 & $(88.12 \%)$ & 58 & $(65.17 \%)$ & 28 & $(31.46 \%)$ & 3 & $(3.37 \%)$ \\
\hline School management & 82 & $(81.19 \%)$ & 79 & $(96.34 \%)$ & 2 & $(2.44 \%)$ & 1 & $(1.22 \%)$ \\
\hline Senior centre & 68 & $(67.33 \%)$ & 38 & $(55.88 \%)$ & 3 & $(4.41 \%)$ & 27 & $(39.71 \%)$ \\
\hline Sewage treatment & 85 & $(84.16 \%)$ & 42 & $(49.41 \%)$ & 16 & $(18.82 \%)$ & 27 & $(31.76 \%)$ \\
\hline Solid waste collection & 92 & $(91.09 \%)$ & 45 & $(48.91 \%)$ & 22 & $(23.91 \%)$ & 25 & $(27.17 \%)$ \\
\hline Solid waste treatment & 90 & $(89.11 \%)$ & 10 & $(11.11 \%)$ & 19 & $(21.11 \%)$ & 61 & $(67.78 \%)$ \\
\hline Stadiums and arenas & 62 & $(61.39 \%)$ & 52 & $(83.87 \%)$ & 4 & $(6.45 \%)$ & 6 & $(9.68 \%)$ \\
\hline Street cleaning & 79 & $(78.22 \%)$ & 69 & $(87.34 \%)$ & 6 & $(7.59 \%)$ & 4 & $(5.06 \%)$ \\
\hline Theatres & 55 & $(54.46 \%)$ & 53 & $(96.36 \%)$ & 1 & $(1.82 \%)$ & 1 & $(1.82 \%)$ \\
\hline Tourism promotion & 92 & $(91.09 \%)$ & 85 & $(92.39 \%)$ & 1 & $(1.09 \%)$ & 6 & $(6.52 \%)$ \\
\hline $\begin{array}{l}\text { Traffic control and } \\
\text { planning }\end{array}$ & 82 & $(81.19 \%)$ & 80 & $(97.56 \%)$ & 1 & $(1.22 \%)$ & 1 & $(1.22 \%)$ \\
\hline Urban re-qualification & 73 & $(72.28 \%)$ & 70 & & 0 & & 3 & $(4.11 \%)$ \\
\hline Veterinary services & 86 & $(85.15 \%)$ & 79 & $(91.86 \%)$ & 5 & $(5.81 \%)$ & 2 & $(2.33 \%)$ \\
\hline Water distribution & 95 & $(94.06 \%)$ & 68 & $(71.58 \%)$ & 12 & $(12.63 \%)$ & 15 & $(15.79 \%)$ \\
\hline Youth development & 46 & $(45.54 \%)$ & 36 & $(78.26 \%)$ & 3 & $(6.52 \%)$ & 7 & $(15.22 \%)$ \\
\hline $\begin{array}{l}\text { Total Provision } \\
\qquad(N=101)\end{array}$ & & 2843 & 2209 & $(77.70 \%)$ & 319 & $(11.22 \%)$ & 315 & $(11.08 \%)$ \\
\hline
\end{tabular}


Table 5 displays multinomial logit estimates for the choice of external provision by local decision-makers as an alternative to hierarchical, in-house solutions for the production of public goods and services. The assumption is that local officials prefer hierarchical solutions as a default, but the transaction costs factors influence the decision to externalise. Three specifications are included. The first specification is the full model including service characteristics, political environment, and control variables. The second specification incorporates service characteristics as the only set of independent variables and the third includes all economic and political transaction costs variables. These specifications are included as a check for consistency in the behaviour of the coefficients and standard errors of the estimates.

\section{Findings}

The overall results confirm the theoretical expectations that transaction costs play a crucial role in the decision to externalise the production of local public services. The stronger result concerns service characteristics. Highly specific assets are externalised primarily using network/partnership mechanisms supporting the argument that there is less potential for opportunistic behaviour when contracting with other governments and nonprofit organisations (Lamothe, Lamothe, \& Feiock 2008). The evidence indicates that markets are the least preferred mechanism to produce highly specific assets, which also concurs with prior findings (Carr, LeRoux and Shrestha 2009; Nelson 1997).

Regarding service measurability, the results are even more unequivocal in terms of the theoretical prediction of transaction costs analysis. For complex services there is a clear preference for in-house production when market externalisation is the alternative. The choice between hierarchical and network mechanisms is unclear as we do not find evidence that one is favoured over the other. In all, Portuguese local officials seem to prefer a more conservative approach in the production of complex services. The local bureaucracy or other arrangement under direct supervision of local officials is regarded as the best way to control service delivery when contracts are hard to write and enforce.

The findings concerning political transaction costs suggest that stability is associated with direct service provision through in-house bureaucracies, whereas political or administrative turmoil leads local officials to search for externalisation options. This is inconsistent with the idea that political transaction costs hinder externalisation, but supports the argument that local officials prefer external alternatives in the face of internal conflict as a circumvention strategy to avoid service disruptions or to shift blame to external providers (Clingermayer \& Feiock 1997; Feiock, Clingermayer, \& Dasse 2003; Hood 2007; Tavares \& Camões 2010).

The results concerning the impact of the financial status of the municipality upon externalisation are worth analysing. The strongest point 


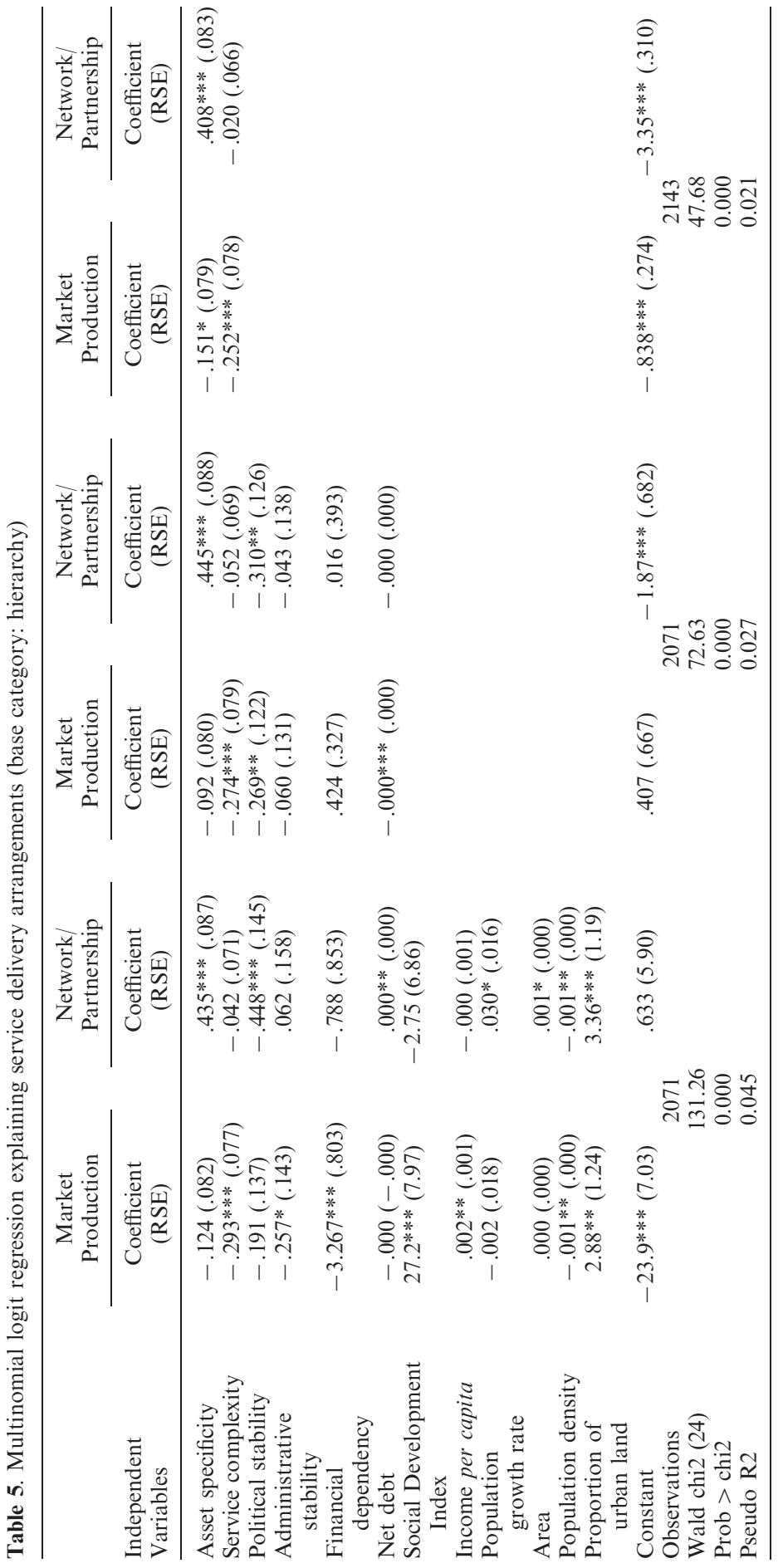


that can be made is that as the level of financial dependency increases, the probability of adopting market solutions decreases compared to hierarchical mechanisms. Pallesen (2004) explains this situation using the expression "the politics of good times". The author states that a good financial condition leads to the adoption of externalisation because there is less friction caused by public unions at the local level. In Portugal, local governments that are highly dependent from central government transfers seem to display riskaverse strategies consistent with conservative preferences over service production alternatives. Under conditions of financial dependency and budgetary constraints the margin of error is extremely small, and it does not allow local officials to engage in innovative and more uncertain options such as externalisation. These findings are in line with the idea that officials resist experimenting with innovative mechanisms of governance and are also less enthusiastic regarding the adoption of New Public Management reforms (Rodrigues \& Araújo 2006).

Concerning community characteristics, we anticipated that higher levels of socioeconomic and demographic changes could promote the use of both market and network mechanisms. Table 5 confirms this expectation. The level of social development, per capita personal income, and the proportion of urban land are positively associated with the use of market mechanisms. The same conclusion is valid for the relationship between the percentage of urban land use and network mechanisms. Population density is the single finding that contradicts our prior expectations. One possible explanation for this counterintuitive result is that local officials in highly dense jurisdictions are able to secure scale economies by keeping service production in-house.

Table 6 displays the relative risk ratios for the independent variables and the percentage change in predicted probabilities. The odds ratios or relativerisk ratios (RRR) represent the impact of each variable in the choice of external governance mechanisms compared to the base outcome (hierarchy). The percentage change in predicted probabilities is calculated by varying each independent variable from its minimum to its maximum observed value in the sample while setting the remaining independent variables at their mean values. The percentages indicate the increase or decrease in probability of external production compared to hierarchical/direct provision.

The analysis of service characteristics confirms that economic transaction costs play an important role in the choice of governance mechanisms. As expected, more complex services are less likely to be contracted with private vendors. An increase in one unit in the difficulty of measurement scale reduces the probability of using market mechanisms as an alternative to hierarchy by $25 \%$. On the other hand, higher levels of asset specificity promote the use of network mechanisms. Substantively, a one unit change in the asset specificity scale increases the likelihood of partnership/network production by $55 \%$. This effect is extremely strong, since the variation in predicted probabilities is close to $400 \%$, increasing from $3.6 \%$ when asset specificity is at its minimum to $18.05 \%$ at the maximum value. 
Table 6. Relative risk ratio values and marginal effects

\begin{tabular}{|c|c|c|c|c|}
\hline & \multicolumn{2}{|c|}{$\begin{array}{l}\text { Hierarchy versus } \\
\text { Market Production }\end{array}$} & \multicolumn{2}{|c|}{$\begin{array}{c}\text { Hierarchy versus } \\
\text { Partnerships/Networks }\end{array}$} \\
\hline & RRR & $\begin{array}{l}\text { Percentage change } \\
\text { in predicted } \\
\text { probabilities } \\
\text { from minimum to } \\
\text { maximum values }\end{array}$ & RRR & $\begin{array}{l}\text { Percentage change } \\
\text { in predicted } \\
\text { probabilities } \\
\text { from minimum to } \\
\text { maximum values }\end{array}$ \\
\hline Asset specificity & .884 & & $1.55^{* * *}$ & $394.52 \%$ \\
\hline Service complexity & $.746^{* * *}$ & $-64.77 \%$ & .956 & \\
\hline Political stability & .826 & & $.639 * * *$ & $-52.21 \%$ \\
\hline Administrative stability & $.774^{*}$ & $-37.38 \%$ & 1.06 & \\
\hline Financial dependency & $.038 * * *$ & $-0.91 \%$ & .455 & \\
\hline Net debt & 1.00 & & $1.00 * *$ & $811.15 \%$ \\
\hline $\begin{array}{l}\text { Social Development } \\
\text { Index }\end{array}$ & $6.26 \mathrm{e}+11^{* * *}$ & $1110.31 \%$ & 0.064 & \\
\hline Income per capita & $1.002 * *$ & $421.39 \%$ & 0.999 & \\
\hline Population growth rate & 0.998 & & $1.030 *$ & $151.72 \%$ \\
\hline Area & 1.000 & & $1.001^{*}$ & $69.59 \%$ \\
\hline Population density & $0.999 * *$ & $-94.43 \%$ & $0.999 * *$ & $-98.49 \%$ \\
\hline $\begin{array}{l}\text { Proportion of } \\
\text { urban land }\end{array}$ & $17.903^{* *}$ & $227.02 \%$ & $28.648 * * *$ & $325.57 \%$ \\
\hline
\end{tabular}

The predicted probabilities of each production alternative: hierarchy $(80.3 \%)$, market $(9.83 \%)$ and networks/partnerships $(9.87 \%)$. The percentage change in predicted probabilities is calculated by varying each independent variable from its minimum to its maximum observed value and setting the remaining independent variables at their means. The percentages indicate the increase or decrease in probability of external production compared to hierarchical/direct provision. ${ }^{*} \mathrm{p}<.10 ;{ }^{*} \mathrm{p}<.05 ; * * * \mathrm{p}<.01$; two-tailed tests.

Analysing political and administrative stability, we verify that in both cases, higher levels of stability promote the use of hierarchic mechanisms. While political stability is associated with a reduction in the likelihood of service production using network arrangements, administrative stability is primarily linked to less reliance on private sector firms. Both effects have similar magnitudes, indicating that externalisation is preferred in jurisdictions dealing with internal turmoil.

In spite of the robustness of the result, financial dependency has a negligible impact upon choice. In contrast, the effect of budgetary surplus upon contracting with networks/partnerships is the most impressive in our transaction costs analysis. Both findings support our hypothesis that externalisation is more common in times of economic prosperity. The transaction costs associated with external service delivery, particularly the loss of political control over service production represent a lesser risk when budgetary surplus and financial independency are the norm.

\section{Conclusions and implications}

This work emphasises both the economic transaction costs associated with service characteristics and the political transaction costs ensuing from the 
political arena where the outsourcing decision occurs. The analysis of Portuguese local service delivery confirms prior findings that service characteristics influence the decision concerning governance mechanisms (Brown and Potoski 2003; Levin and Tadelis 2007; Carr, LeRoux, and Shrestha 2009). The externalisation of services involving highly specific assets favours contractual options involving fewer risks of opportunistic behavior, namely the use of partnerships with not-for-profit organisations or with other governments. Highly complex and hard-to-measure activities are more amenable for delivery through hierarchical mechanisms to avoid contractual agreements that are difficult to design and monitor. These results are aligned with the theoretical predictions of transaction costs analysis (Williamson 1985; 1996) and supported by other recent empirical research (Carr, LeRoux, \& Shrestha 2009; Lamothe, Lamothe, \& Feiock; see Bel \& Fageda (2007) for a meta-analysis).

The findings concerning political transaction costs represent a key contribution to the literature. Higher levels of political and administrative instability point to the adoption of market mechanisms and network partnerships rather than hierarchic mechanisms. These results can be understood in light of recent empirical work (Clingermayer \& Feiock 1997; Feiock, Clingermayer, Shrestha, \& Dasse 2007; Tavares \& Camões 2010). Political instability leads to the externalisation of services to shift responsibility for the provision to external agents. Once service provision is delegated to external actors, local officials can avoid blame for service disruptions.

Public provision of municipal services can also be regarded as a delegation decision to help shed some light on these findings. If the municipality produces the service directly, the delegation of authority is hierarchical and the costs incurred by elected officials are associated with internal monitoring of subordinate behavior. When the service is produced by contract with other agents, the delegation of authority is external, and agency costs are involved in monitoring activities.

Framing contracting out as a delegation decision is not entirely new in the literature. Andrew Whitford (2010) suggests that the delegation to subnational units in a federalist system can be cast as a theory of franchising, where the delegation of power involves both constraints to franchisee behaviour and limitations to cross-franchise negative externalities. Likewise, the externalisation of services entails franchise-like properties since it secures efficiency gains from market competition and coordination benefits from hierarchical authority.

Hence, local government officials regard the delegation decision as a trade-off between different types of transaction costs. Externalisation is favoured when the inefficiencies resulting from agency costs and loss of political control to the external provider are surmounted by the presence of significant political transaction costs associated with in-house production. Contracting becomes the logical response to circumvent not only political and/or administrative turmoil, but also to address environmental 
turbulence. Highly dynamic and complex political environments lead to the adoption of market mechanisms and networks replacing traditional production using in-house bureaucracies. Externalisation alternatives appear more frequently in more urban settings experiencing economic prosperity and significant population growth because these solutions are better at addressing preference diversity. In contrast, hierarchical solutions are preferred when political transaction costs are low compared to economic transaction costs associated with contracting decisions.

In sum, the results indicate that both service characteristics and political contexts are determinants of externalisation decisions, underlining the resistance of Portuguese local governments to implement New Public Management reforms as a fashion. Whenever New Public Management governance mechanisms are adopted, it has been because they are regarded as appropriate management tools to provide specific services, not simply to mimic practices in other jurisdictions. Future work should provide more detail concerning the choice of governance mechanisms in specific service areas such as public works, economic development, and social services.

One important limitation of our study is associated with capturing the actual decision-making process followed by local government officials. In fact, officials have first to decide whether or not to provide a service to their constituents and only after a positive answer to this question will they engage in studying alternative production modes. Although this thought process is frequently recognised in theory, research designs have systematically failed to address this fact. This would require a selection model where the first equation estimates the determinants of the decision to provide the service and the second equation employs a nominal dependent variable to reflect the production decision. Currently, standard statistical software packages do not allow the sequential treatment of provision and production decisions, but it is important to recognise this limitation in the research design in order to correct it in future work.

\section{Acknowledgement}

The Portuguese Science and Technology Foundation (Fundação para a Ciência e Tecnologia - FCT) [grant number PEst-OE/CJP/UI0758/20112012] provided financial support for this research. Any opinions, findings, and conclusions or recommendations expressed in this material are those of the authors and do not necessarily reflect the views of the Fundacão de Ciência e Tecnologia (FCT).

\section{References}

Aldrich, J.H. and Nelson, F.D., 1984. Linear probability, logit, and probit models. Newbury Park, CA: Sage.

Alexander, E., 1995. How organizations act together. Luxembourg: Gordon and Breach Publishers. 
Beetham, D., 1991. Models of bureaucracy, In: G. Thompson, J. Mitchell, R. Levacic, and J. Frances, eds. Markets, hierarchies and networks. Sage.

Bel, G., and Fageda, X., 2007. Why do local governments privatise public services? A survey of empirical studies. Local Government Studies, 33(4), 517-534.

Bel, G. and Fageda, X., 2010. Partial privatisation in local services delivery: An empirical analysis of the choice of mixed firms. Local Government Studies, 36(1), 129-149.

Blau, P., and Meyer, M., 1971. Bureaucracy in modern society. Random House.

Borcherding, T., 1988. Some revisionist thoughts on the theory of public bureaucracy, European Journal of Political Economy, 4, 47-64.

Borooah, V.K., 2002. Logit and probit: Ordered and multinomial models. Thousand Oaks, CA: Sage.

Brown, T., and Potoski, M, 2003. Transaction cost and institutional explanations for government services production decisions. Journal of Public Administration Research and Theory, 13(4), 441-468.

Brown, T., and Potoski, M., 2004. Managing the public service market. Public Administration Review, 64(6), 656-668.

Brown, T., and Potoski, M., 2005. Transaction costs and contracting. Public Performance and Management Review, 28 (3), 326-351.

Brown, T., Potoski, M., and Slyke, D., 2006. Managing public service contracts: Aligning values, institutions, and markets, Public Administration Review, 66(3), 323-331.

Burns, T., and Stalker, G., 1961. The management of innovation. London: Tavistock.

Caetano, M. 1982. Manual de direito administrativo (10th ed.). Coimbra: Livraria Almedina.

Carr, J., LeRoux, K. and Shrestha, M., 2009. Institutional ties, transaction costs, and external service production. Urban Affairs Review, 44(3), 403-427.

Carvalho, J., Fernandes, M.J., Jorge, S. and Camões, P., 2006. Anuário Financeiro dos Municipios Portugueses. Braga: NEA.

Clingermayer, J., and Feiock, R., 1997. Leadership turnover, transaction costs, and external city service delivery, Public Administration Review, 57(3), 231-239.

Clingermayer, J., Feiock, R., and Stream, C., 2003. Governmental uncertainty and leadership turnover: Influences on contracting and sector choice for local services. State and Local Government Review, 35(3), 150-160.

Coase, R., 1937. The nature of the firm. Economica, 4, 386-405.

Dixit, A.K., 1996. The making of economic policy: A Transaction cost politics perspective. Cambridge, MA: MIT Press.

Feiock, R., Clingermayer, J., and Dasse, C., 2003. Sector choices for public service delivery. Public Manangement Review, 5(2), 163-175.

Feiock, R., Clingermayer, J., Shrestha, M., and Dasse, C., 2007. Contracting and sector choice across differente types of municipal services. State and Local Government Review, 39(2), 72-83.

Feiock, R. and Jang, H.S., 2009. Nonprofits as local government service contractors. Public Administration Review, 70 (July/August), 668-680.

Ferris, J.M., 1986. The decision to contract out: An empirical analysis. Urban Affairs Quarterly, 22(2): 289-311.

Ferris, J.M., and Graddy, E.A., 1986. Contracting out: For what? With whom? Public Administration Review, 46(4), 333-344.

Ferris, J.M., and Graddy, E.A., 1997. New public management theory: lessons from institutional economics and government contracting. Advances in International Comparative Management Supplement, 3, 89-104.

Ferris, J.M., and Graddy, E.A., 1991. Production cost, transaction cost, and local government contractor choice. Economic Inquiry, XXIX, 541-554.

Frant, H., 1996. High-powered and low-powered incentives in the public sector. Journal of Public Administration Research and Theory, 6 (3), 365-382.

Hood, C., 1998. The art of the state. Oxford: Oxford University Press.

Hood, C., 2007. What happens when transparency meets blame avoidance? Public Management Review, 9(2), 191-210. 
INE - Instituto Nacional de Estatística, 2006. Anuário das Estatísticas Regionais. Available@ http://www.ine.pt

Joassart-Marcelli, P., and Musso, J., 2005. Municipal service provision choices within a Metropolitan area. Urban Affairs Review 40(4), 492-519.

Lamothe, S., Lamothe, M., and Feiock, R., 2008. Examining local government service delivery arrangements over time. Urban Affairs Review, 44 (1), 27-56.

LeRoux, K. and Carr, J., 2007. Explaining local government cooperation on public works: Evidence from Michigan. Public Works Management and Policy, 12(1), 344-358.

Levin, J.D. and Tadelis, S., 2007. Contracting for government services: Theory and evidence from U.S. cities. NBER Working Paper series, Vol. W13350.

Liao, T.F., 1994. Interpreting probability models: Logit, probit, and other generalized linear models. Thousand Oaks, CA: Sage.

Livermore, H.V., 1976. A new history of Portugal, 2nd Edition. Cambridge: Cambridge University Press.

Manique, A.P., 1989. Mouzinho da Silveira liberalismo e administração pública. Lisboa: Livros Horizonte.

Nelson, M., 1997. Municipal government approaches to services delivery: An analysis from transactions cost perspective. Economic Inquiry XXXV, 82-96.

North, D., 1990. Institutions and a transaction-cost theory of exchange. In: J.E. Alt and K.A. Shepsle, eds. Perspectives on positive political economy. Cambridge, UK: Cambridge University Press.

Oliveira, A.C., 1996. A República e os Municípios. In: C. Oliveira, História dos Municípios Portugueses. Lisboa: Círculo de Leitores.

Opello, W. C., 1983. The continuing impact of the Old Regime on Portuguese political culture. In: L.S. Wheeler, ed. In search of modern Portugal. Madison, WI: The University of Wisconsin Press, 182-199

Ostrom, V., and Ostrom, E., 1977. Public goods and public choices. In: E.S. Savas, ed. Alternatives for delivering public services: Toward improved performance. Boulder, CO: Westview Press, 7-49.

Pallesen, T., 2004. A political perspective on contracting out: The politics of good times. Experiences from Danish local governments. Governance: An International Journal of Policy Administration and Institutions, 17(4), 573-587.

Pereira, A., and Almeida, C.d., 1985. Conhecer as Autarquias Locais. Porto: Porto Editora.

Peterson, P., 1981. City limits. Chicago: University of Chicago Press.

Rodrigues, M., 2009. Governance mechanisms: Alternative coordenation strategies in Portuguese local government. PhD Thesis. Braga: Universidade do Minho.

Rodrigues, M., and Araújo, J. F., 2006. A nova gestão pública na administração local: O caso do Noroeste de Portugal. Revista Galega do Eixo-Atlântico, 9, 59-80.

Shrestha, M. and Feiock, R.C., 2010. Transaction cost, exchange embeddedness, and interlocal cooperation for local public goods supply. Political Research Quarterly, doi: 10.1177/ 1065912910370683.

Stein, R., 1993. Arranging city services. Journal of Public Administration Resarch and Theory, 3(1), 66-92.

Tavares, A.F., and Camões, P.J., 2007. Local service delivery choices in Portugal: A political transaction costs framework. Local Government Studies, 33(4), 535-553.

Tavares, A.F., and Camões, P.J., 2010. New forms of local governance: A theoretical and empirical analysis of municipal corporations in Portugal. Public Management Review, 12 (5), 587-608.

Verhoest, K., Peters, G., Beuselinck, E., Meyers, F., and Bouckaert, G., 2004. How coordination and control of public organizations by government interrelate: An analytical and empirical exploration [online]. Comparative Public Organization Data Base for Research and Analysis. Available from:http://www.publicmanagement-cobra.org [Accessed 8 Nov 2007]

Weber, M., 1947. Legitimate authority and bureaucracy. In: The theory of social and economic organisation. New York, NY: Free Press. 


\section{M. Rodrigues et al.}

Whitford, A.B., 2010. Can consolidation preserve local autonomy? Mitigating vertical and horizontal dilemmas. In: R.C. Feiock and J.T. Scholz, eds. Self-organizing federalism. Cambridge, MA: Cambridge University Press, 33-50.

Williamson, O., 1981. The economics of organization. American Journal of Sociology, 87(3), $548-577$.

Williamson, O., 1985. The economic institutions of capitalism. New York, NY: Free Press.

Williamson, O., 1996. The mechanisms of governance. Oxford: Oxford University Press.

Wittman, D., 1989. Why democracies produce efficient results. Journal of Political Economy, 97(6), 1395-1424. 